Submit: 07-08-2017; Revision: o8-09-2017; Publish: 30-10-2017

\title{
THE ANALYSIS OF ANTI-CORRUPTION BEHAVIOR (CASE STUDY: BATAM CENTRAL BUREAU OF STATISTIC (BPS) SERVICES)
}

\author{
Raja Dachroni 1) , Ady Muzwardi 2)* \\ 1 Program Studi Ilmu Pemerintahan, , STISIPOL Raja Ali Haji. Jalan W.R. Supratman, \\ Tanjunpinang, Kepulauan Riau, 38371, Indonesia. \\ 2 Program Studi Ilmu Hubungan Internasional, Universitas Maritim Raja Ali Haji. Jalan Raya \\ Dompak, Tanjunpinang, Kepulauan Riau, 38371, Indonesia \\ * Korespondensi Penulis. E-mail: ady.muz16@gmail.com., Telp: +6281328407846
}

\begin{abstract}
Anti-Corruption Behaviour Survey is a national programme that measures individual Indonesians' anti-corruption knowledge, attitudes and experiences. The Survey also assesses the nationwide implementation of the National Anti-Corruption Strategy for the Prevention and Eradication of Corruption (STRANAS-PPK) to establish a culture of zero tolerance for corruption in the country. A key activity in support of this assessment is to set the baselines for the STRANAS-PPK anti-corruption strategies.
\end{abstract}

This study is aimed to analyze the mainly determined the anti-corruption behavior on Batam Central Bureau of Statistic (BPS). This research used descriptive statistical analysis method. Data collected in this research use interview technique, observation, and questioner. This sample of this research has been taken from government institution/ Regional Work Unit (SKPD)/ Research and Education Institution : National and International/ Mass Media/Banking/Private.

The result of the analysis indicates that Batam Central Bureau of Statistic (BPS) is relatively high compared with the average score of hope, The low average score of expectation shows that anti-corruption conditions in Batam Central Bureau of Statistic (BPS) services are clean enough.

Keywords: Corruption, Behavior, Services 



\section{Jurnal Ilmu Pemerintahan, 2 (2), Oktober 2017 - 97}

Raja Dachroni, Ady Muzwardi

\section{INTRODUCTION}

Being In the past few years, Indonesia has been consistently listed by Transparency International as one of the most corrupt counties in the world. The country ranked 80th out of 85 countries surveyed by the Corruption Perception Index of the organization in 1998, 96th out of 99 countries in 1999, and 85th out of 90 countries this year region (Arifianto, 2010).

Corruption, for the purposes of this report, is defined as the use of authority for private gain. This definition is broad, embracing the three elements of corruption as commonly described in the widely used acronym in Indonesia, KKN (coruption, collusion, nepotism). Corruption is more a symptom of the failure of accountability than a disease. Hence, the report focuses on the processes and institutions of accountability and adapts to its purposes a framework developed for the World Bank's World Development Report 2004.

Based on this framework, we look at accountability in Indonesia from the perspective of the relationship between citizens in whom sovereignty resides and the politicians/policy makers they elect to represent them as President and in Parliament, between the politicians and policy makers in turn and the implementing agencies/service providers, the Ministries or agencies of government, and between the front-line service providers (those delivering the service, such as a postman, a traffic cop or amunicipalsweeper), and citizens/consumers (World Bank, 2003)

\section{a. Corruption}

Corruption is the abuse of public office or entrusted power for private gain. In addressing corruption, it is useful to distinguish between various forms of corruption, such as political and bureaucratic corruption, and important to develop a clear understanding of how it relates to adjacent terms, such as rentseeking. At the core of the concept of corruption is a moral and ethical dimension, which may be translated into legal provisions in various ways. Abuse of entrusted power as a principle tends to be recognized as a problem all over the world. The effort to combat corruption can be based on different rationales - the drive for greater aid effectiveness and domestic legitimacy of aid and/or an understanding of corruption as ethically undesirable. In the current development policy discourse, a consequentialist approach is generally dominant. This focuses on the negative effects of corruption on growth on the one hand, and on distribution or poverty on the other hand (e.g. greater exclusion of the poor as a result of petty corruption). However, denouncing corruption exclusively because of its bad consequences makes the anti-corruption agenda vulnerable to partial - and possibly shifting - interpretations of empirical results. (Kolsta, 2008). The most popular and simplest definition of corruption is that it is the abuse of public power for private benefit. From this definition, it should not be concluded that corruption cannot exist within private sector activities (Tanzi, 1998)

\section{b. Behaviour}

Behaviour is every action by a person that can be seen or heard. Behaviour must be defined in a way that is both observable and measurable so 


\section{Jurnal Ilmu Pemerintahan, 2 (2), Oktober 2017 - 98}

Raja Dachroni, Ady Muzwardi

that everyone working with the child has a good understanding of what the behavior looks like and sounds like (Alberto \& Troutman, 2003).

Behaviour can be defined as the way in which an individual behaves or acts. It is the way an individual conducts herself/himself with Root Causes of Behaviour Differences. The following are the root causes of behavior differences (UNESCO, 2000):

1) Individual differences;

2) Differences in family patterns;

3) Impairment/disabilities;

4) Environmental factors;

5) Psychological factors.

Behaviour should be viewed in reference to a phenomenon, an object or person. It can be seen in reference to society norms, or the way in which one treats others or handles objects. Behaviour, therefore, is the way individual acts towards people, society or objects. It can be either bad or good. It can be normal or abnormal according to society norms. Society will always try to correct bad behavior and try to bring abnormal behavior back to normal.

c. Service Quality

Service quality can be defined as an overall judgment similar to attitude towards the service and generally accepted as an antecedent of overall customer satisfaction have defined service quality as the ability of the organization to meet or exceed customer expectations. It is the difference between customer expectations of service and perceived service (Zeithaml et al., 1990). Perceived service quality results from comparisons by customers of expectations with their perceptions of service delivered by the suppliers (Zeithaml et al., 1990). If expectations are greater than performance, then perceived quality is less than satisfactory and hence customer dissatisfaction occurs (Parasuraman et al. (1988),). Service quality is needed for creating customer satisfaction and service quality is connected to customer perceptions and customer expectations. Oliver (1997) argues that service quality can be described as the result from customer comparisons between their expectations about the service they will use and their perceptions about the service company. That means that if the perceptions would be higher than the expectations the service will be considered excellent, if the expectations equal the perceptions the service is considered good and if the expectations are not met the service will be considered bad (Kabir, 2010) bangsa.

\section{RESEARCH METHODOLOGY}

In general, the method of data analysis of survey results used is descriptive statistical analysis method. This analysis is used to summarize the presentation of survey data so that important information is generated into simpler and simpler forms, such as in tables and graphs. The results of data analysis ultimately lead to explanation and interpretation (interpretation) of the data generated.

Respondents who are recorded in this study are data consumers who have used BPS data and have come directly to BPS or have contacted BPS by phone/email / website and others. A number of respondents 40 (forty) respondents with the composition as follows:

- Government agencies at least 60 percent

- Private as much as 10 percent 


\section{Jurnal Ilmu Pemerintahan, 2 (2), Oktober 2017 - 99}

Raja Dachroni, Ady Muzwardi

- Institute for Education and Research about 10 percent

- Others as much as 20 percent

Consumers of the data in question are those who have a purpose to look for data, such as Ministry/government institution/ Regional Work Unit (SKPD)/ Research and Education Institution: National and International/ Mass Media/ Banking/ Private Companies/ Others. Work units, especially those domiciled in Batam City or foreign institutions (domiciled in Batam City).

\section{a. Sampling Techniques}

Sampling was taken use purposive technique in which the chosen 40 respondents were those of officials at divide for 7 group such as :

- Ministry/government institution

- Regional Work Unit (SKPD)

- Research and Education institution: National and International

- Mess Media

- Banking

- Private Sector

- NGO, Freelance, Entrepreneur are occasionally assigned or whose correlation is related to service regarding BPS.

\section{b. Data Compiling and Analysis}

The data compiled consists of primary and secondary data. Primary data was respondents' opinion which demonstrated perception of organizations/institutions in regard to BPS services. This statements for this research include:

1. System and Procedure service had been caused corruption
2. Services officer offered the quick of service outside the time and process.

3. Services officer take the offer the quick of service outside the time and process.

4. Services officer give the services give the service outside the time and process.

5. There have brokering practice

6. Cost of service does not correspond with service prescribed rates.

7. officer requesting financial rewards services/goods outside the official rate

8. service officer received an offer to perform services outside the official rate

9. Services officer had been differentiating treatment of service

10. There have the kind of service is indicated of fraud

11. Services officer had been taken gift/goods (gratification)

\section{c. Types of research}

Analysis of survey results used is descriptive statistical analysis method. This analysis is used to summarize the presentation a survey.

\section{d. Location and time of the research}

The research was conducted toward Provincial organizations of Riau island and Batam city. The data gathering was done in 2015

\section{RESULTS AND DISCUSSION}

The anti-corruption index is needed to get an idea of the readiness of units of service in order to establish zones Integrity and Corruption-Free Region (WBK) and the Regional Clean Serving Bureaucracy (WBBM). 
The results of the data analysis AntiCorruption Index Batam overall CPMs are presented in Table 1.

Table 1. Average Score Satisfaction Index and Expectations And Environmental Behavior of Anti-Corruption in BPS

\begin{tabular}{|c|c|c|c|}
\hline It is assessed & $\begin{array}{l}\text { average } \\
\text { Service } \\
\text { Quality }\end{array}$ & $\begin{array}{c}\text { Average } \\
\text { Improvement } \\
\text { Expectations }\end{array}$ & $\begin{array}{c}\text { Anti- } \\
\text { Corrupt } \\
\text { ion } \\
\text { Index }\end{array}$ \\
\hline $\begin{array}{l}\text { System and } \\
\text { Procedure } \\
\text { service had } \\
\text { been caused } \\
\text { corruption }\end{array}$ & 59.17 & 46.77 & 4.46 \\
\hline $\begin{array}{l}\text { Services officer } \\
\text { offered the } \\
\text { quick of } \\
\text { service outside } \\
\text { the time and } \\
\text { process }\end{array}$ & 63.33 & 51.61 & 5.26 \\
\hline $\begin{array}{l}\text { Services officer } \\
\text { take the offer } \\
\text { the quick of } \\
\text { service outside } \\
\text { the time and } \\
\text { process. }\end{array}$ & 67,50 & 60.48 & 6.57 \\
\hline $\begin{array}{l}\text { Services officer } \\
\text { give the } \\
\text { services give } \\
\text { the service } \\
\text { outside the } \\
\text { time and } \\
\text { process. }\end{array}$ & 67.50 & 59.68 & 6.49 \\
\hline $\begin{array}{l}\text { There have } \\
\text { brokering } \\
\text { practice }\end{array}$ & 80.83 & 60.48 & 7.87 \\
\hline $\begin{array}{l}\text { Cost of service } \\
\text { does not } \\
\text { correspond } \\
\text { with service } \\
\text { prescribed } \\
\text { rates. }\end{array}$ & 71.67 & 60,00 & 6,92 \\
\hline $\begin{array}{l}\text { officer } \\
\text { requesting } \\
\text { financial } \\
\text { rewards } \\
\text { services/goods } \\
\text { outside the } \\
\text { official rate } \\
\end{array}$ & 83.62 & 55.83 & of 7.52 \\
\hline $\begin{array}{l}\text { service officer } \\
\text { received an } \\
\text { offer to }\end{array}$ & 77.59 & 59.17 & 7.39 \\
\hline
\end{tabular}

\begin{tabular}{llcc}
\hline \multicolumn{1}{c}{ It is assessed } & $\begin{array}{c}\text { average } \\
\text { Service } \\
\text { Quality }\end{array}$ & $\begin{array}{c}\text { Average } \\
\text { Improvement } \\
\text { Expectations }\end{array}$ & $\begin{array}{c}\text { Anti- } \\
\text { Corrupt } \\
\text { ion } \\
\text { Index }\end{array}$ \\
\hline $\begin{array}{l}\text { perform } \\
\text { services } \\
\text { outside the } \\
\text { official rate }\end{array}$ & & & \\
\hline $\begin{array}{l}\text { Services officer } \\
\text { had been } \\
\text { differentiating } \\
\text { treatment of } \\
\text { service }\end{array}$ & 80.83 & 54.84 & 7.14 \\
\hline $\begin{array}{l}\text { There have the } \\
\text { kind of service } \\
\text { is indicated of } \\
\text { fraud }\end{array}$ & 80.00 & 54.03 & \\
\hline $\begin{array}{l}\text { Services officer } \\
\text { had been taken } \\
\text { gift/goods } \\
\text { (gratification) }\end{array}$ & 83.33 & 5806 & 7.79 \\
\hline \multicolumn{1}{c}{ average } & 74.12 & 56.45 & \\
\hline & & & \\
\hline
\end{tabular}

Based on Table 1 can be explained that the overall average satisfaction scores and anti-corruption index within Batam BPS are relatively high compared with the average score of hope, The low average score of expectation shows that anti-corruption conditions in Batam city BPS environment are clean enough so that expectations of lower anti-corruption behavior improvement. This is consistent with the anti-corruption index scores were quite high at 74.38 to the quality of anti-corruption behavior is good.

The results of the data analysis Anticorruption Behavior Index based activity where the respondent, respondent education, and service type are presented in Table 1, Table 2 and Table 3.

Table 1. Conduct Anti-Corruption Index BPS Service activities According Points Respondents 
Jurnal Ilmu Pemerintahan, 2 (2), Oktober 2017 - 101

Raja Dachroni, Ady Muzwardi

\begin{tabular}{|c|c|c|c|}
\hline Points Activity & $\begin{array}{c}\text { Average } \\
\text { Quality } \\
\text { of } \\
\text { Service }\end{array}$ & $\begin{array}{c}\text { On average } \\
\text { expectation } \\
\text { Repair }\end{array}$ & $\begin{array}{l}\text { Anti- } \\
\text { Corruption } \\
\text { Index }\end{array}$ \\
\hline $\begin{array}{l}\text { Ministry/gover } \\
\text { nment } \\
\text { institution }\end{array}$ & 71.97 & 59.85 & 71.94 \\
\hline $\begin{array}{l}\text { Regional Work } \\
\text { Unit (SKPD) }\end{array}$ & 72.18 & 57.75 & 72.61 \\
\hline $\begin{array}{l}\text { Research and } \\
\text { Education } \\
\text { Institution: } \\
\text { National and } \\
\text { International }\end{array}$ & 80.68 & 4205 & 80.07 \\
\hline Mass Media & 78.41 & 50.00 & 78.41 \\
\hline Banking & & & \\
\hline $\begin{array}{l}\text { Private } \\
\text { Companies }\end{array}$ & 81.06 & 60.61 & 80.94 \\
\hline Others & 75.00 & 50.00 & 75.00 \\
\hline
\end{tabular}

Table 1 can be explained that based on place of activity of respondents, the highest anticorruption index achieved by the group of respondents Private Company amounted to 80.94 to the quality of anticorruption behavior "B" and the performance of anti-corruption "Good". As for the anti-corruption index lows, although still including the quality of anti-corruption category "B" and the performance of anti-corruption "Good", is the group of the Ministry / Government Institutions (71.94).

Table 2. Behavior Index BPS Service Anticorruption by Educational Respondents

\begin{tabular}{lccc}
\hline Education & $\begin{array}{c}\text { Service } \\
\text { Quality } \\
\text { Average }\end{array}$ & $\begin{array}{c}\text { Average } \\
\text { Hope } \\
\text { Repair }\end{array}$ & $\begin{array}{c}\text { Anti- } \\
\text { Corruption } \\
\text { Index }\end{array}$ \\
\hline SLTA down & & & \\
\hline $\begin{array}{l}\text { D1 / D2 / } \\
\text { D3 }\end{array}$ & 67.05 & $46.590^{-}$ & 67.99 \\
\hline D4/S1 & 73.67 & 55,59 & 73.82 \\
\hline S2 / S3 & 82.58 & 70.45 & 83.60
\end{tabular}

In Table 3 can explain that based on the type of service used by the respondent, the index reached the highest anti-corruption behavior by service type Digital Library at 78.91 to the quality of anti-corruption behavior "B" and the performance of anti-corruption "Good". As for the anti-corruption index lows, although still including the quality of anticorruption category "B" and the performance of anti-corruption "Good", is 
the kind of service Consultancy Data Use (70.09).

\section{CONCLUSION}

The anti-corruption index within Batam BPS is relatively high compared with the average score of hope, The low average score of expectation shows that anti-corruption conditions in Batam city BPS environment are clean enough so that expectations of lower anti-corruption behavior improvement. This is consistent with the anti-corruption index scores were quite high at 74.38 to the quality of anti-corruption behavior is good.

\section{RECOMENDATION}

The service officer in BPS is expected to explain to the consumer that the service officer will not offer service to the consumer to accelerate the process outside the procedure and outside the time. In addition, BPS needs to make a system operational procedure (SOP) for more clear and easy so that consumers are not likely to cause corruption.

\section{REFERENCE}

UNITED NATIONS Office on Drugs and Crime (2004) The Global Programme Against Corruption Un Anti-Corruption Toolkit. Vienna

Prabha Ramseook-Munhurrun (2010). "Service Quality In The Public Service, Vol,3, Mauritius: International Journal of Management And Marketing Research

Riberio (1993) The Components Of Service Quality. Porto. University of Porto.

Arvind. K.Jain (2001) Corruption A Review.
Vol.15. Journal of economy surveys

Ivar Kolsta. (2008). Corruption, Anticorruption Efforts and Aid: Do Donors Have the Right Approach?. Research project (RP-05-GG) of the Advisory Board for Irish Aid.

Md.Hussain Kabir (2010) Service Quality Expectations, perceptions and satisfaction about Service Quality at Destination Gotland - A case study . Gotland University

UNESCO (2000) Regional Training Seminar on Guidance and Counselling Module 4. Behaviour Modification

Vito Tanzi (1998)Corruption Aroung The World. International Monetary Fund $U B$.

\section{PROFILE AUTHOR}

Raja Dachroni, he is a lecturer of govermental studies in STISIPOL Raja Ali Haji Tanjungpinang, Riau Island. Become a member of ADIPSI in 2016-2017, and become Chairman of LPPM.

Ady Muzwardi, he is a lecturer of UMRAH at international Relations program. Born in Metro City, October 16, 1982, graduated from S1 International Relations University Muhammadiyah Yogyakarta, S2 International Relations UMY 2014, and S2 Science Goverment UMY 2015. Currently serves as Head of Laboratory of International Relations UMRAH. 